\title{
BLOCKADE BY ESERINE OF THE CEREBRAL CORTICAL EFFECTS OF ALLOFERIN: A FURTHER EVIDENCE OF CHOLINERGIC INHIBITORY MECHANISM
}

\author{
Vinod BHARGAVA \\ Department of Pharmacology, H.P. Medical College, Simla (H.P.), India
}

Accepted April 23, 1973

\begin{abstract}
In rats anaesthetised with pentobarbitone, somatosensory evoked potentials, produced by stimulation of contralateral or ipsilateral forepaws were used to measure the activity in different neuronal pathways. Computer derived averages of 32 consecutive responses yiglded a stable and consistent measurement of the croked potentials. The drugs were applicd to the cerebral cortex by using cortical cun technique and changes were measured in croked potentials. Cortical application of alloferin increased the amplitude of the carly negative wave of the cortical evoked potentials. This effect of alloferin was blucked by prior treatment of the cortex with eserinc. It appears that the excitant effect of alioferin on the cortex was the result of disinhibition of cortical cholinergic inhibitory mechanism.
\end{abstract}

In recent years, cortical inhibition has received increasing atlention from Neurophysiologists and Pharmacologists. There is considerable evidence of an 'Inhibition blockade' mechanism for the excitant offect of strychnine, curare and atropine $(1,2)$. The neurohumoral mechanism involved in contical inhibition is still however debatable. Application of alloferin to the exposed cerebral cortex leads to abnormality in the soliatosensory evoked potentials after a few minutes (1). This consists of a surface negative wave (peak latency 21-23 msec) which attains an amplitude five to ten limes greater than that of the normal evoked potentials, probably reflecting an excessive depolarization of the apical dendrites of pyramidal neurones. This effect of alloferin is similat to that of strychnine or curare (1). The effect of strychnine is blocked by eserine (3), suggesting that the excitant effect of strychnine occurs as a result of disinhibition of the cholinergic inhibiory mechanism in the cortex as described by Phillis and York $(4,5)$. The present study was undertaken to study the blocking of strychnine like action of diallyl nortoxiferine dihydrochloride (alloferin) by eserine to further strengthen the hypothesis of cortical cholinergic inhibitory mechanism.

\section{MATERIALS AND METHODS}

Male rats of CFE strain (Sprague-Dawley from Carworth, Europe) weighing 250$300 \mathrm{~g}$ were anaesthetised with pentobarbitone $(50 \mathrm{mg} / \mathrm{kg}$ initially, then $12 \mathrm{mg} / \mathrm{kg}$ every $30 \mathrm{~min}$ ). By the technique of Bhargava and Meldrum (1) animals were prepared for the recording of cortical somatosensory evoked responses. Computer derived averages of 32 consecutive somatosensory evoked potentials from both cortices, in response to the 
stimulation of contralateral and ipsilateral forepaws were recorded. Drugs were applied to the pial surface by injection through polythene tubing connected to a perspex ring and removed by multiple washing with artificial cerebrospinal fluid (CSF) (6). Drugs were freshly dissolved in CSF at $37^{\circ} \mathrm{C}$ for each experiment. The drugs were applied to one cortex while the other cortex was bathed with normal CSF and served as control throughout the experiment. In each experiment, the effect of a $15 \mathrm{~min}$ application of alloferin was initially tested on left and right cortex. After 1 hr recovery from the effect of alloferin, $10^{-3} \mathrm{M}$ eserine sulphate was applied to one cortex for $60 \mathrm{~min}$ and changes in the evoked potentials by escrine were studied. Alloferin was reapplied to the eserine treated cortex to determine whether or not eserine moditied the effect of alloferin.

A continuous polygraphic record of cortical and rectal temperatures was taken by thermocouples.

\section{RESULTS}

Normal form of somatoschisory evoled polental under pentobarbitone

An afferent volley from a peripheral nerve evokes a diphasic potential on the surface of the somatosensory cortex. The potential changes in the primary receiving areat in the first $50 \mathrm{mscc}$ after contralateral stimulus show an initial positive wave $\left(\mathrm{P}_{1}\right)$ with a peak at $7 \pm 1 \mathrm{msec}(\mathrm{N}-65)$ and subsequent one $\left(\mathbf{P}_{2}\right)$, at $11.5 \pm 1.8 \mathrm{msec}(\mathrm{N}=65)$, followed by a longer lasting negative wave $\left(\mathrm{N}_{2}\right)$, peak at $40 \perp-6.2 \mathrm{msec}(\mathrm{N}-65)$. Some records show a sharp early negative wave $\left(\mathrm{N}_{1}\right)$ with peak latency at $16.3 \perp 2.9 \mathrm{msec}(\mathrm{N}=27)$, as reported earlier (1).

\section{Effect of alloferin}

Cortical application of CSF containing various concentrations of alloferin for 15 min constantly led to an appearance of an abnormally large surlace negative wave (peak latency $21-23 \mathrm{msec}$ ). The threshold concentration was $3 \times 10^{-4} \mathrm{M}$, which produced an effect after $15-20 \mathrm{~min} .2 \times 10^{-3} \mathrm{M}$ alloferin produced an increase in the early negative wave of the somatosensory evoked potential in $5.5+0.7 \mathrm{~min}$, which became maximal after 13.5 -2.1 min and lasted for $42.5,-3.5 \mathrm{~min}$ after washing out the drug. The increase in the amplitude of the early negative wave after $3 \times 10^{-4} \mathrm{M}$ was $0.5+0.2 \mathrm{mV}, 10^{-3} \mathrm{M} 2.0$. $0.4 \mathrm{mV}$ and after $2 \times 10^{-3} \mathrm{M}$ alloferin was $3.6 \pm 1.3 \mathrm{mV}$. A direct linear relationship between log concentrations and the amplitude of the early negative wave was seen.

The first positive wave constantly showed no change in latency amplitude or duration after alloferin. The second positive wave however, at times showed a slight increase in the amplitude which was not statislically significant. On the control cortex the cortical responses to contralateral stimulation showed no changes. Ilowever, a biphasic positive negative wave on ipsilateral stimulation appeared when the drug treated hemisphere showed an abnormal negative wave. This wave reversed at a depth of $1-1.5 \mathrm{~mm}$ below the surface when recorded by subcortical electrode.

Blockade by eserine of the cortical effect of alloferin

In some experiments, in order to determine whether or not the strychnine-like effect 


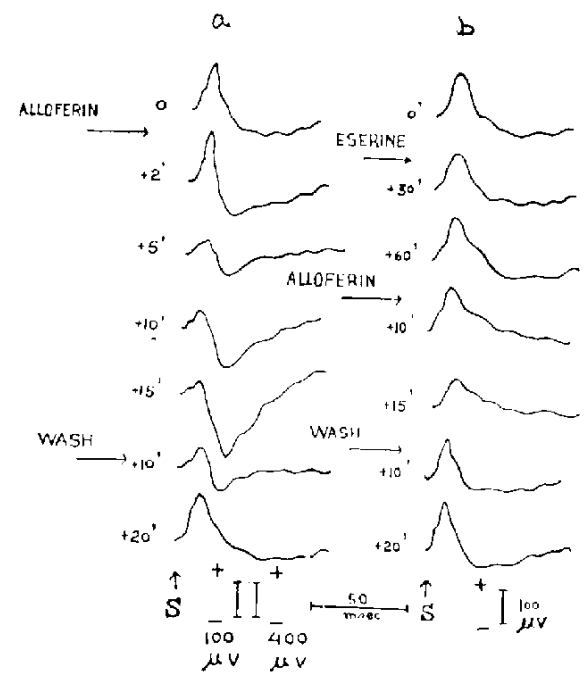

Fic. 1. (a) Effect of cortical application of alloferin $2 \times 10^{-3} \mathrm{M}$, (b) the same cortex $1 \mathrm{hr}$ later. The effect of eserine $10^{-3} \mathrm{M}$, followed by alloferin $2 \times 10^{-3} \mathrm{M}$. The $400 \mathrm{pr}$ calibration applies to the traces in at times alloferin $5 \mathrm{~min}$ to wash + 10 min. Each trace is the average of thirty-1wo consecutive responses recorded during 130 min after stimulation of the contralateral forepaw. Positivity of the clectrocle at the somatosensory cortex is show upwards. The $I(00$ gu calibration applies to all other traces.

TABLi: 1. Effect of cortical application of alloferin $15 \mathrm{~min}$ ) on amplitude of the early negative wave (N1) (peak latency $22 \mathrm{msec}$ ) of the cortical eroked potentials before and after prior treatment of the cortex with eserine sulphate $\left(10^{-3} \mathrm{M}\right)$ for $60 \mathrm{mins}$

\begin{tabular}{lcccccc} 
Conc. of drug & $\begin{array}{c}\text { Amplitude NI }(\mathrm{mv}) \\
\text { contro })\end{array}$ & $\begin{array}{c}\text { Amplitude NI (mv) } \\
\text { escrinte }\end{array}$ & $\begin{array}{c}\text { No. } \\
\text { drug }\end{array}$ & $\%$ Inhibition \\
$3 \times 10^{4} \mathrm{M}$ & 0 & $0.48 \cdots 0.21$ & 0 & 0 & 5 & $100 \%$ \\
$10^{-3} \mathrm{M}$ & 0 & $2.0 \pm 0.4$ & 0 & $0.5 \pm 0.4$ & 5 & $75 \%$ \\
$2 \times 10^{-3} \mathrm{M}$ & 0 & $3.6 \pm 1.3$ & 0 & $1.2 \pm 0.3$ & 5 & $66 \%$ \\
\hline
\end{tabular}

of alloferin was the result of action on the cholinergic inhibitory system; the effect of 15 min application of different concentrations of alloferin was initially lested on the left and the right somatosensory cortex. After one hour recovery from the effect of alloferin, $10^{-3} \mathrm{M}$ eserine sulphate was applied to one cortex for $60 \mathrm{~min}$. Escrine itself did not modify the cortical evoked potentials, however, it did block the ellect of alloferin on the early negative wave of the cortical evoked potentials. The effect of $3: 10^{-1} \mathrm{M}$ alloferin was blocked by $100 \%$, that of $10^{-3} \mathrm{M}$ by $75 \%$ and of $2,10^{-3} \mathrm{M}$ by $66 \%$ (Table 1 ).

\section{DISCUSSION}

Electrical stimelation of the forepaw of the rat under pentobarbitone produces biphasic positive negative potentials at the primary receiving area. These positive negative waves are mostly derived from differences in potentials between portions of cortical 
neurons situated at different levels. The surface positive waves are considered to represent activity in the depth of the cortex while early negative wave represents conduction of the response towards the cortical surface, presumably as a result of depolarization of apical dendrites of pyramidal neurons (7). The present study shows that cortical application of alloferin results in appearance and augmentation of a surface negative wave (peak latency $22 \mathrm{msec}$ ) of the primary cortical evoked potentials. The effect is closely similar to that of curare, strychnine and cobra venom $(1,8)$. A common mechanism of action would, therefore, appear to be responsible for the characteristic action of alloferin, curare and cobra venom. This could be disinhibition of the cortical cholinergic inhibitory mechanism. The strychnine like effect of alloferin was blocked by prior application of eserine to the cortex. One possible interpretation of this antagonistic effect of eserine is that alloferin blocks a cholinergic inhibitory mechanism in the cortex, which normally prevents massive depolarization of the apical dendrites of pyramidal neurons. Phillis and York $(4,5)$, have shown an inhibitory mechanism acting on the cells in layers II, III and IV in the cortex. The cells are inhibited by cholinomimetic drugs and blocked by strychnine, curare and atropine. Thes this inhibitory mechanism and an enhancement of negative wave of cortical evoked potentials seen in present experiments have the same drug sensitivity. It appcars that alloferin and related drugs produce their excitant effect by blocking cholinergic inhibitory mechanism.

The phenomenan of cortical inhibition is an unresolved problem and the exact mechanism and site of action of cortical excitant drugs remains to be elucidated until the identity of the cortical inhibitory transmitter is known.

Acknowledgements: The author wishes to express his gratitude to Dr. B.S. Meldrum of M.R.C., Neuropsychiatry Unit, Carshalton, U.K. for suggestions and criticism, to the Wellcome Trust for receipt of a Fellowship and to Roche Products Ltd. U.K. for the gift of alloferin.

\section{REFERENCES}

1) Bilargaya, V.K. AND Meldrly, B.S.: Br. J. Pharmacol. Chemother. 37, 112 (1969)

2) Chateleld, P.O. ANd PuRpule, D.P.: Electroen. Nerrophysiol. 6, 287 (1954)

3) Bhargavi, V.K. and Meldrum, B.S.: Nature 230, 152 (1971)

4) Phill.ls, J.W. AND YoRK, D.H.: Brain. Res. 5, 517 (1967)

5) Phillis, J.W. ANd Yokk, D.H.: Brain. Res. 10, 297 (1968)

6) Bradbury, M.W.B. and Davson, H.: J. Physiol. 170, 195 (1964)

7) ECCles, J.C.: Electroen. Neturophysiol. 3, 449 (1951)

8) Bhargava, V.K. and Meldrum, B.S.: Br. J. Pharmacol. Chemother. 39, 455 (1970) 